\title{
THE EFFECTS OF VASCULAR CATHETERIZATIONS UPON HEART RATE AND BLOOD PRESSURE BEFORE AORTO-CORONARY BYPASS SURGERY
}

\author{
Luc Quintin, David G. Whalley, J. Earl Wynands and J.E. Morin
}

\begin{abstract}
Ten patients presenting for aorto-coronary bypass surgery were premedicated with their regular dose of propranolol and nitrates and diazepam $0.15 \mathrm{mg} \cdot \mathrm{kg}^{-1}$ by mouth, morphine 0.15 $\mathrm{mg} \cdot \mathrm{kg}^{-1}$ and scopolamine $0.4 \mathrm{mg}$ intramuscularly, 60 to 90 minutes before arrival in the operating room.

Venous, arterial and pulmonary artery catheterizations were done under local anaesthesia. No significant changes were noted in systolic blood pressure and rate pressure product.

Heart rate was decreased after internal jugular puncture and for the remainder of the study. $\mathrm{Pa}_{\mathrm{CO}_{2}}$ increased and $\mathrm{Pa}_{\mathrm{O}_{2}}$ decreased from values obtained the day before operation. Cardiovascular stability during vascular catheterization was achieved by emphasizing a detailed preoperative explanation, maintenance of beta-blockade up to the time of operation, substantial sedative premedication, and the liberal use of local anaesthesia.
\end{abstract}

Key Words: Measurement Techniques, vascular catheterization, Blood pressure, heart rate.

\section{INTRODUCTION}

THERE HAVE BEEN conflicting reports ${ }^{1-3}$ in the literature concerning the haemodynamic effects of the insertion of vascular catheters in awake patients before cardiac surgery. Lunn, et al.' concluded that the placement of pulmonary artery or radial artery catheters in unanaesthetized patients produces significant increases in systolic blood pressure and heart rate. They noted in their study that these increases were sufficient to produce angina in patients with coronary artery disease not receiving propranolol and recommended that a reasonable depth of anaesthesia be established before the insertion of vascular catheters. Gardner, et al. $^{2}$ agreed with Lunn et al. with respect to pulmonary artery catheter insertion but felt that radial artery catheters could be inserted safely before the induction of anaesthesia.

Waller, et al. ${ }^{3}$ however, demonstrated no significant changes in heart rate, systolic blood pressure and rate-pressure product during vascu-

Luc Quintin, M.Sc., M.D., Resident; David G. Whalley, M.B., Ch.B., F.F.A.R.C.S., F.R.C.P.(C), Assistant Anaesthetist; J. Earl Wynands, M.D., F.R.C.P.(C), Senior Anaesthetist; J.E. Morin, M.D., F.R.C.S.(C), Chief, Cardiovascular Thoracic Surgery Service; Royal Victoria Hospital, McGill University, Montreal, Quebec.

Address for reprints: J. Earl Wynands, M.D., Department of Anaesthesia, Royal Victoria Hospital, 687 Pine Ave West, Montreal, Quebec, H3A IAl. lar cannulation in patients scheduled for aortocoronary bypass surgery. They concluded that it is both safe and prudent to insert monitoring cannulae before anaesthetic induction. We were thus stimulated to investigate our own routine in a group of awake sedated patients presenting for aorto-coronary bypass surgery and maintained on propranolol and nitrates.

\section{METHODS}

This investigation was approved by the ethics committee for clinical study of the Royal Victoria Hospital.

Ten patients presenting for aorto-coronary bypass surgery were studied (Table I). All patients were being treated with propanolol and a nitrate preparation. At the preoperative visit each received a detailed explanation of the procedures to be performed by the anaesthetist before induction of anaesthesia. Flurazepam $30 \mathrm{mg}$ was prescribed as night sedation. On the morning of the operation each patient was given his maintenance dose of propanolol and nitrate preparation before receiving a sedative premedication consisting of diazepam $0.15 \mathrm{mg} \cdot \mathrm{kg}^{-1}$ by mouth, morphine $0.15 \mathrm{mg} \cdot \mathrm{kg}^{-1}$ and scopolamine $0.4 \mathrm{mg}$ intramuscularly, 60 to 90 minutes before operation. Upon arrival in the operating room a five lead electrocardiogram was attached to the patient and lead $V_{5}$ was monitored throughout the study. ${ }^{4}$ Under local anaesthesia with lidocaine 
TABLE 1

Patient Data

\begin{tabular}{lll}
\hline \hline Number of patients & & 10 \\
Sex (male) & & 10 \\
Age (years) & mean \pm sd & $58.5 \pm 9.2$ \\
Height (m) & mean \pm sd & $1.74 \pm 0.04$ \\
Weight (kg) & mean \pm sd & $78 \pm 10.3$ \\
Body surface area $\left(\mathrm{m}^{2}\right)$ & mean $\pm \mathrm{sd}$ & $1.92 \pm 0.11$ \\
Unstable angina & & 2 \\
Previous myocardial infarction & mean \pm sd & $102 \pm 75$ \\
Daily propranol dose (mg) & Class II & 2 \\
New York Heart Association & III & 3 \\
& IV & 5 \\
Elasped time between premedication and & mean \pm sd & $75 \pm 21$ \\
$\quad$ and arrival in operating room (min) & & \\
\hline
\end{tabular}

2 per cent, $16 \mathrm{G}$ and $18 \mathrm{G}$ catheters were placed in a suitable vein and in a radial artery.

The supine patient was then placed in a $10^{\circ}$ head down position, the head turned to the left. The area over the right internal jugular vein was prepared with iodine in alcohol 0.5 per cent and the site was draped. A transparent Steridrape was used to facilitate patient communication and comfort. The area over the internal jugular vein was infiltrated with local anaesthetic. A Cathlon ${ }^{\circledR}$ $16 \mathrm{G}$ catheter was introduced into the right internal jugular vein and the patient was returned to the horizontal position. A Cordis ${ }^{\otimes} 8 \mathrm{Fr}$ SwanGanz introducer was inserted and a $7 \mathrm{Fr}$ SwanGanz catheter subsequently placed with appropriate monitoring of the electrocardiogram and pulmonary pressures. Direct arterial and venous pressures were measured with Bentley Trantec ${ }^{\boxplus}$ transducers suitably calibrated and displayed on a General Electric Four Traces monitor. Measurements of heart rate and systolic blood pressure were taken by the same observer after each of the following events: arrival in the operating room, intravenous catheterization, radial artery catheterization, infiltration of local anaesthesia in the neck, preparation of the site of internal jugular vein catheterization, catheterization of internal jugular vein, introduction of the Cordis ${ }^{\text {(t) }}$ Swan-Ganz catheter introducer, and Swan-Ganz catheter insertion.

The systolic blood pressure was measured by the Riva-Rocci method for the first two observations, i.e. upon arrival in the operating room and at the time of intravenous catheterization, and subsequently by transduction, amplification and digital display. The heart rate was counted for one minute for each observation.
Two arterial blood gas samples per patient were obtained, the first taken under local anaesthesia the day before operation and the second after placement of the Swan-Ganz catheter. On both occasions, patients were supine and breathing room air. Arterial blood gas analysis was done on a Corning apparatus (model 175).

Statistical analysis was done using Student's " $t$ " test for paired data. " $P$ " values of less than 0.05 were considered significant and the observations obtained upon arrival in the operating room were used as control.

\section{RESULTS}

The mean time ( $\pm 5 d$ ) from arrival in the operating room to placement of catheters was 5 minutes $( \pm 2.2)$ for intravenous catheter, 12.7 minutes $( \pm 7.3)$ for intra-arterial catheter and 35.3 minutes $( \pm 8.6)$ for Swan-Ganz catheter.

The results obtained for heart rate (HR), systolic blood pressue (SBP) rate pressure product (RPP), and $\mathrm{Pa}_{\mathrm{O}_{2}}, \mathrm{~Pa}_{\mathrm{Ca}_{2}}$ are displayed in Tables II and III.

No significant changes in SBP and RPP were seen. However, HR decreased significantly after internal jugular puncture, remaining below control for the remainder of the study.

The values of $\mathrm{Pa}_{\mathrm{CO}_{2}}$ and $\mathrm{Pa}_{\mathrm{O}_{2}}$ obtained after Swan-Ganz catheter insertion were significantly higher and lower respectively than those values obtained the day before.

\section{Discussion}

Our observations are in agreement with Waller, et $a l^{2}$ and demonstrate that vascular cathe- 


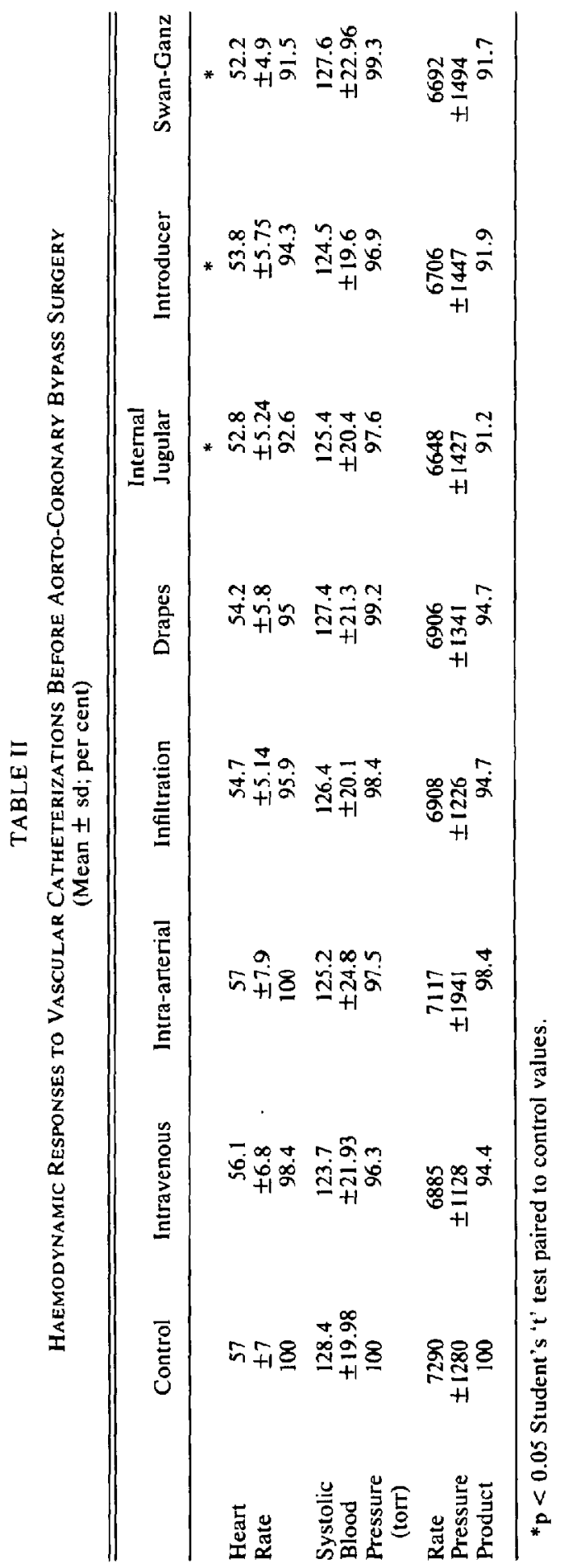




\section{TABLE III}

$\mathrm{Pa}_{\mathrm{O}_{2}}$ and $\mathrm{Pa}_{\mathrm{CO}_{2}}$ Values Obtained the Day Before OPERATION ('WARD') AND UPON SWAN GANZ CATHETER ISERTION ('SWAN GANZ') (mean $\pm \mathrm{sd}$; per cent of 'Ward' values)

\begin{tabular}{ccc}
\hline & Ward & Swan Ganz \\
\hline $\mathrm{Pa}_{\mathrm{O}_{2}-\mathrm{kPa}}$ & $10.15 \pm 0.99$ & $9.13 \pm 0.71^{*}$ \\
(torr) & $(76.33 \pm 7.47)$ & $(68.67 \pm 5.34)$ \\
& 100 & 89.9 \\
$\mathrm{~Pa}_{\mathrm{CO}_{2}-\mathrm{kPa}}$ & $5.25 \pm 0.48$ & $6.10 \pm 0.31^{*}$ \\
(torr) & $(39.33 \pm 3.64)$ & $(45.89 \pm 2.31)$ \\
& 100 & 116 \\
\hline
\end{tabular}

${ }^{*} \mathrm{p}<0.05$ Student's 'test' test paired to 'Ward' values.

terization can be done before aorto-coronary bypass surgery without a deleterious increase in HR, SBP and, by inference, in myocardial oxygen demand..$^{5.6}$

Patients were drowsy upon arrival in the operating room but all were arousable and oriented. Some of them fell asleep during catheterization. Upon questioning one week after the operation, no patient recalled the experience before induction of general anaesthesia as being unpleasant. The amnesic properties of the diazepam-scopolamine combination may account for the amnesia experienced by three patients for this period.

Isolated premature ventricular contractions occurred in six patients during passage of the Swan-Ganz catheter through the right ventricle. All patients were taking propranolol regularly before operation and no further anti-arrythmic agent was administered.

The significant decrease in $\mathrm{Pa}_{\mathrm{O}_{2}}$ is probably due to hypoventilation induced by the morphinescopolamine premedication. ${ }^{8}$ However, an association between hypoxaemia and nitrate administration has been reported. ${ }^{9}$ The normal control $\mathrm{Pa}_{\mathrm{CO}_{2}}$ rules out the possibility of hyperventilation when arterial blood gases were deter- mined without the benefit of local anaesthesia. The increase in $\mathrm{Pa}_{\mathrm{CO}_{3}}$ may be due to the use of morphine and/or to the fact that some patients were asleep during the procedure. Relative hypoxia and hypercarbia during this period may be an indication for the administration of oxygen to eliminate a possible cause of preoperative myocardial ischaemia. ${ }^{8}$

In conclusion, cardiovascular stability during vascular catheterization was achieved by emphasizing a detailed preoperative explanation, maintenance of beta-blockade up to the time of operation, substantial sedative premedication and the liberal use of local anaesthesia.

1. LunN, J.K., Stanley, T.H., Webster, L.R., et al. Arterial blood pressure and pulse rate responses to pulmonary and radial arterial catheterization prior to cardiac and major vascular operations. Anesthesiology 51:265-269, 1979.

2. Gardner, R., Parker, J.\& Wong, H.C. Preoperative invasive monitoring and coronary artery disease. Anesthesiology 52: 525, 1980.

3. WALLER, J.L., ZAIDEN, J.R., KAPLAN, J.A., et al. Hemodynamic responses to vascular cannulations before coronary bypass surgery. Anesth. Anal 59: 563-564, 1980

4. KaPLAN, J.A. \& King, S.B. The precordial electrocardiographic lead $\left(V_{5}\right)$ in patients who have coronary artery disease. Anesthesiology 45: 570$574,1976$.

5. Braunwald, E. Control of myocardial oxygen consumption. Physiologic and clinical considerations. Am. J. Cardiol. 27: 416-432, 1971.

6. RoBinson, B.F. Relation of heart rate and systolic blood pressure to the onset of pain and angina pectoris. Circulation 25: 1073-1083, 1967.

7. Frumin, J., Herekar, V.R. \& Jarvik, M.E. Amnesic actions of diazepam and scopolamine in man. Anesthesiology 45: 406-412, 1976.

8. Kopman, E.A. \& Ramirez-Inawat, R.C. Arterial hypoxemia following premedication in patients with coronary artery disease. Canad. Anaesth. Soc. J. 27: 132-134, 1980.

9. Kopman, E.A., Weygandt, G.R., Bauer, S. \& Ferguson, T.B. Arterial hypoxemia following the administration of sublingual nitroglycerin. Am Heart. J. 96: 444-447, 1978.

\section{RÉSUMÉ}

Dix patients opérés pour pontages aorto-coronariens reçurent leur dose habituelle de propranolol, de nitrates et de diazepam $0.15 \mathrm{mg} \cdot \mathrm{kg}^{-1}$ p.o., morphine $0.15 \mathrm{mg} \cdot \mathrm{kg}^{-1}$ i.m., scopolamine $0.4 \mathrm{mg}$. i.m., de 60 à 90 minutes avant leur arrivée à la salle d'opération.

Les canules veineuse, artérielle et de l'artère pulmonaire furent insẻrées sous anesthésie locale. Aucun changement significatif de la pression artérielle systolique et du produit fréquence-pression artérielle ne fut enregistré.

Le rythme cardiaque ralentit après la ponction de la jugulaire interne et demeura stationnaire pendant le reste de la période d'observation. La stabilité cardiovasculaire durant les cathétérisations fut obtenue grâce a une explication détaillé du processus avant l'opération ainsi que la maintenance des bloquers beta jusqu'au temps opératoire, une sédation pré-anesthésique profonde et un usage libéral d'anesthésie locale. 